\title{
Spacer-Mediated Synthesis of Bis-spiroketal Disaccharides: Nonsymmetrical Furanose-Pyranose Difructose Dianhydrides
}

\author{
Farida Louis, ${ }^{\text {a,1 }}$ M. Isabel García-Moreno, ${ }^{a}$ Patricia Balbuena, ${ }^{\text {a }}$ Carmen Ortiz Mellet, ${ }^{* a}$ José M. García Fernández*b \\ a Departamento de Química Orgánica, Facultad de Química, Universidad de Sevilla, Profesor García González 1, 41012 Sevilla, Spain \\ Fax +34(954)624960; E-mail: mellet@us.es \\ b Instituto de Investigaciones Químicas, CSIC, Universidad de Sevilla, Américo Vespucio 49, Isla de la Cartuja, 41092 Sevilla, Spain \\ Fax +34(954)460565; E-mail: jogarcia@iiq.csic.es \\ Received 19 March 2007
}

\begin{abstract}
The stereochemical outcome of the dimerization reaction of D-fructose, leading to tricyclic bis-spiroketal systems, can be tuned by inserting a xylylene template between the reacting moieties. Spirocyclization becomes then an intramolecular process, the available conformational space depending on the nature of the tether. The methodology is here illustrated by the stereoselective synthesis of two nonsymmetrical di-D-fructose dianhydrides present in commercial caramel.
\end{abstract}

Key words: acetals, difructose dianhydrides, spiroacetals, oligosaccharides, spiro compounds

The bis-spiroketal unit is present in a wide range of interesting natural products, including several marine toxins and ionophore antibiotics. ${ }^{2}$ This complex architectural arrangement is also the underlying structural motif of a unique family of cyclic disaccharides isolated from microorganisms and higher plants, namely di-D-fructose dianhydrides (DFAs). ${ }^{3}$ During the last decade, DFAs have been recognized as the major products of acidic and thermal activation of fructose and fructose-containing oligosaccharides (sucrose, glycosyl fructoses, inulin), being present in dietary foods such as caramel, chicory, or torrefacted coffee. ${ }^{4}$ The implications of this discovery in human nutrition and the promising prebiotic properties of DFAs have strongly stimulated research in these and related spiro-sugars. ${ }^{5}$

Up to thirteen different diastereomeric DFAs have been identified in commercial foodstuffs, making the synthesis of individual isomers a very difficult issue. Almost quantitative conversions of D-fructose, inulin, sucrose, and isomeric glucosylfructoses into structurally diverse DFAs have been achieved by using anhydrous hydrogen fluoride (HF) as solvent and catalyst. ${ }^{6}$ Separation of pure compounds from these multicomponent mixtures, however, becomes extremely hard. Although the use of pyridinium poly(hydrogen fluoride) complexes, a soft form of HF, let establish some kinetic and thermodynamic relationships, ${ }^{7}$ the low interconversion barriers and the reversibility of the reaction make this approach unsuitable for the preparation of single isomers in most cases. Anchoring the cyclic form of D-fructose by suitable protecting groups

SYNLETT 2007, No. 17, pp 2738-2742

Advanced online publication: 25.09 .2007

DOI: 10.1055/s-2007-991055; Art ID: D08307ST

(C) Georg Thieme Verlag Stuttgart · New York has proven very useful for accessing difuranose (type I; 1-3) and dipyranose (type III; 8, 9) DFAs. High diastereomeric excesses in favor of compounds having different stereochemistry $(\alpha, \beta)$ at both spiroketal centers ( $\mathbf{1}$ and $\mathbf{8}$, respectively), which are thermodynamically more stable, were achieved by performing the spiroketalization reaction in organic solvents under irreversible reaction conditions. ${ }^{8}$ This strategy is, however, unsuitable for the preparation of DFAs incorporating fructofuranose and fructopyranose moieties in the tricyclic core (type II DFAs; 4-7), which can exist in four different diastereomeric combinations. Thus, initial attempts to prepare these compounds from binary mixtures of fructofuranose and fructopyranose precursors led invariably to the simultaneous formation of all type I, type II, and type III DFAs 1-9 (Figure 1).

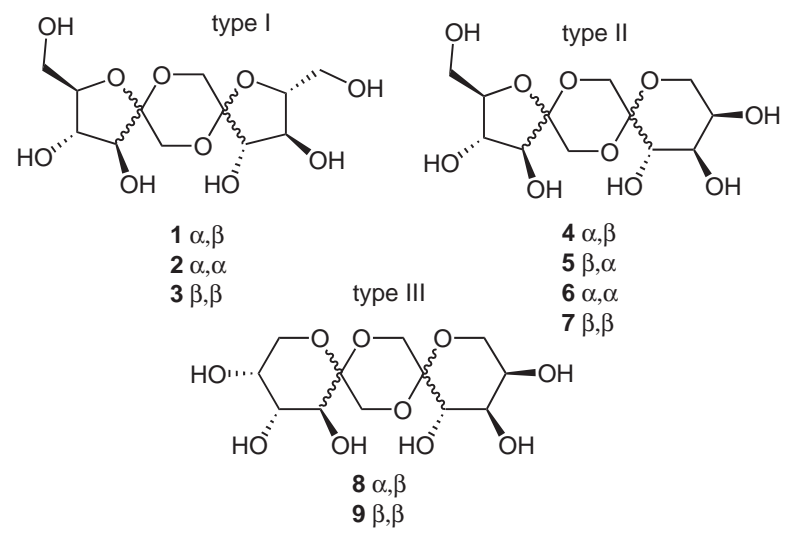

Figure 1 Structures of the bis-spiroketal difructose dianhydrides present in commercial caramel and other foodstuffs

We have recently reported ${ }^{9}$ a new approach for the synthesis of bis-spiroketal systems based on the 'rigid spacer between non-reactive centers' concept previously introduced in oligosaccharide synthesis. ${ }^{10}$ By connecting homologous positions in the reacting moieties through an appropriate tether, stereoselective syntheses of contrathermodynamic ${ }^{11} C_{2}$-symmetric type I and type III DFAs, namely the $\beta, \beta$-diastereomers $\mathbf{3}$ and $\mathbf{9}$, were accomplished. The success of the approach relies on the conformational dissimilarities between derivatives having different or identical configuration at the anomeric positions, which adopt chair or boat arrangements, respectively, at the central dioxane ring to comply with the anomeric 
effect (Figure 2). We speculated that this methodology could be extended to the preparation of type II DFAs by tethering furanose and pyranose building blocks through judiciously chosen bridges. This has now been translated into efficient syntheses of the thermodynamic $\alpha, \beta$-derivative 4 and the contra-thermodynamic $\beta, \alpha$ counterpart 5 .

(a)

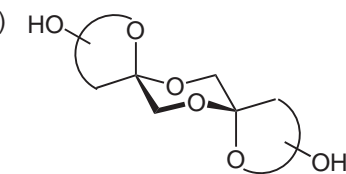

(b)
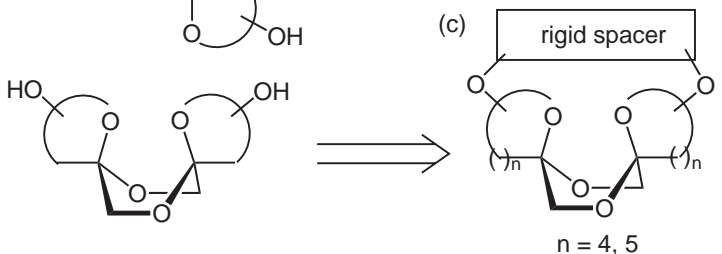

Figure 2 Schematic representation of the chair (a) and boat (b) conformations for DFAs having different or identical configuration at the spiroketal centers. The application of the 'rigid spacer concept' to trap the boat isomers is depicted (c).

Examination of the interatomic relationships for 4-7 in their more stable conformations by computer-generated molecular models revealed that the primary position O-6 in the furanose moiety and position $\mathrm{O}-3^{\prime}$ in the pyranose ring lie much closer in the chair conformers $4(6.0 \pm 0.5$ $\AA)$ and $5(6.5 \pm 0.5 \AA)$ than in the boat DFAs 6 and $7(8.1$ $\pm 1 \AA$ ). Consequently, the introduction of an $m$-xylylene tether (ca. $6 \AA$ ) between these nonreacting hydroxyls was contemplated as a mean for configurational control. Thermodynamic considerations should then result in the predominance of the $\alpha, \beta$-isomer 4 , which is the major compound in thermodynamic mixtures containing the 13 DFA isomers.

The synthesis of the nonsymmetrical O- $6 \rightarrow \mathrm{O}-3^{\prime} m$-xylylene-bridged precursor is illustrated in Scheme 1. Reaction of 1,2:4,5-di- $O$-isopropylidene- $\beta$-D-fructopyranose $(\mathbf{1 0})^{12}$ (one step from D-fructose) with an excess of $\alpha, \alpha^{\prime}-$ dibromo- $m$-xylene led to the corresponding 3-O-bromomethylbenzyl ether 11. Selective removal of the nonanomeric isopropylidene group $(\rightarrow \mathbf{1 2})$ and subsequent standard benzylation provided the fructopyranose building block 13. ${ }^{13}$ Incorporation of the fructofuranose moiety $\mathbf{1 4}^{9 \mathrm{a}}$ (four steps from D-fructose) at the remaining reactive bromobenzyl position afforded the required tethered derivative 15. ${ }^{14}$ Treatment of $\mathbf{1 5}$ with trifluoromethanesulfonic acid (triflic acid, TfOH) in dichloromethane promoted the intramolecular tandem glycosylation-spirocyclization reaction, ${ }^{15}$ zipping up the tricyclic bisspiroketal core to give exclusively the $\alpha, \beta$-configured DFA derivative 16 (59\% isolated yield) ${ }^{16}$ Simultaneous removal of the xylylene and benzyl groups by catalytic hydrogenolysis afforded the target fully unprotected dianhydride 4 in quantitative yield, ${ }^{17}$ whose structure was confirmed by comparison of its spectroscopic and chromatographic properties with an authentic sample ${ }^{2,4 \mathrm{~d}}$ (Scheme 1).

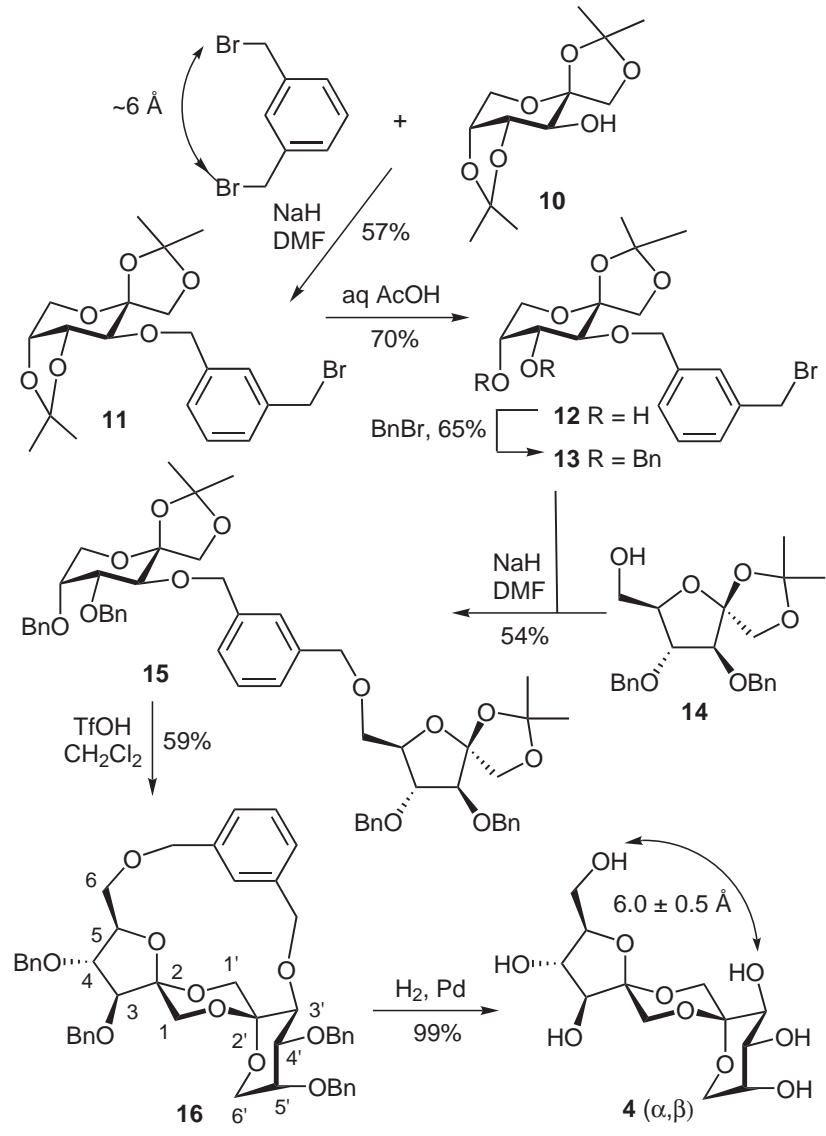

Scheme $1 m$-Xylylene-mediated stereospecific synthesis of DFA 4. The key interatomic distances for the synthetic design are indicated.

The stereospecificity induced by the $m$-xylylene template in the above spirocyclization reaction deserves a further comment. In the intermolecular dimerization, the relative proportion of compounds 4-7 was found to be 60:1:1:10. Therefore, the incorporation of the $\mathrm{O}-6-\mathrm{O}-3^{\prime}$ distance restriction fully prevented the formation of the boat diastereomers $\mathbf{6}$ and $\mathbf{7}$ and further selected the thermodynamic $\alpha, \beta$-chair DFA 4 ( $18 \%$ in the DFA fraction of commercial caramels).

The synthesis of the contra-thermodynamic $\beta, \alpha$-isomer 5 (less than $1 \%$ in the DFA fraction of commercial caramels) represents a much more difficult challenge. The configurational differences between $\mathbf{4}$ and $\mathbf{5}$ are not associated with significant conformational changes, with virtually identical inter-residue distances. Recent crystallographic evidence, ${ }^{9 a}$ however, suggested that contrathermodynamic DFAs exhibit a relatively high conformational flexibility, whereas thermodynamic derivatives are much more rigid. This intrinsic difference could be used with advantage to achieve further diastereoselection. We hypothesized that shortening the O-6-O-3' distance, e.g. by inserting an $o$-xylylene tether (ca. $3 \AA$ ), would provoke a substantial steric constrain in the chair ground-state conformation that would be better accommodated by the $\beta, \alpha$-isomer 5 . 
Replacing the 3-O-(3-bromomethylbenzyl) fructopyranose monomer 13 into the 2-bromomethylbenzyl positional isomer $17^{18}$ in the bridging reaction provided the corresponding nonsymmetrical $o$-xylylene-tethered precursor 18. ${ }^{14}$ Activation of $\mathbf{1 8}$ with triflic acid likewise resulted in bis-spiroketal ring-closing reaction ${ }^{15}$ to give, in this case, a $1: 1.5$ binary mixture of the thermodynamic $\alpha, \beta$-isomer $19^{19}$ and the contra-thermodynamic $\beta, \alpha$-DFA derivative $\mathbf{2 0}^{20}$ (Scheme 2). Their structures were confirmed after transformation into the respective unprotected compounds ${ }^{17} \mathbf{4}$ and $\mathbf{5}$ and comparison of their spectroscopic and gas-chromatographic data with authentic samples. ${ }^{2,4 d}$

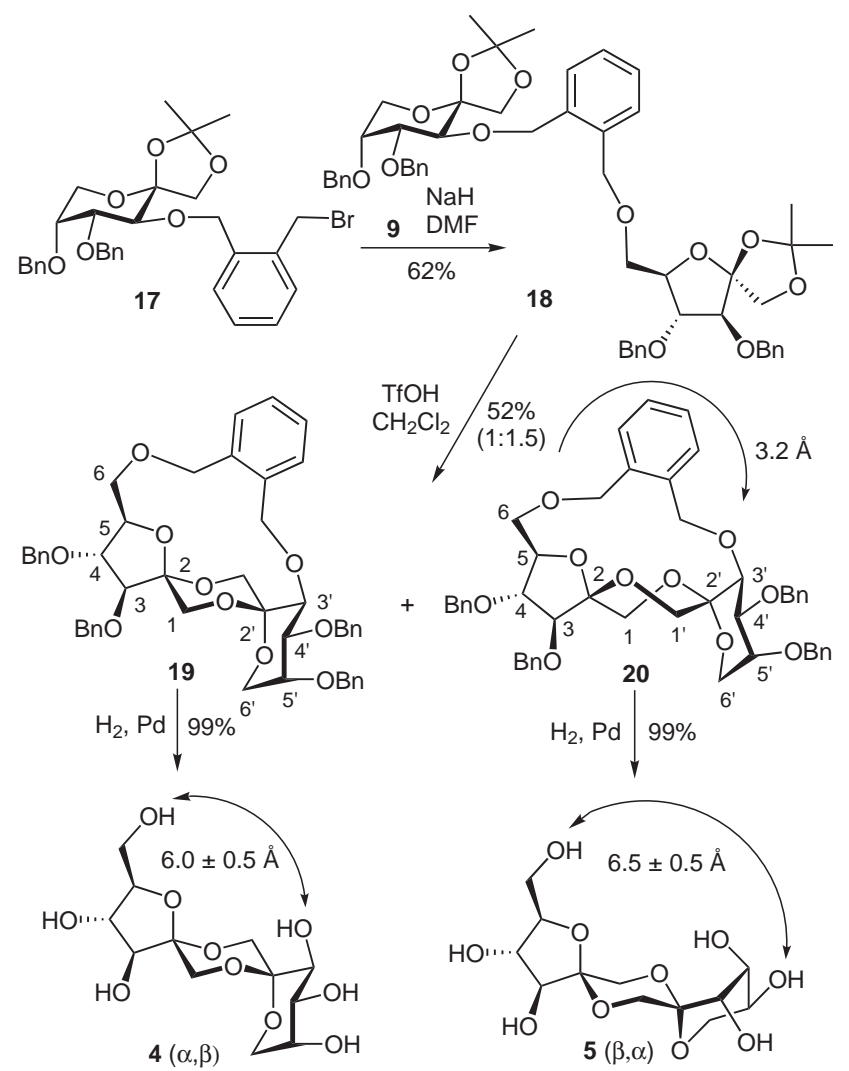

Scheme $2 o$-Xylylene-mediated synthesis of DFA $\mathbf{5}$. The key interatomic distances for the synthetic design are indicated.

The outstanding enhancement in the 5:4 relative proportion (90-fold as compared with the nontemplated reaction) by acting on the spacer length is remarkable. Examination of the ${ }^{1} \mathrm{H}$ NMR data revealed that the $o$-xylylene-tethered $\alpha, \beta$-derivative 19 keeps the same conformation at the sixmembered rings as compared with the $m$-positional isomer $\mathbf{1 6}$ or the unprotected derivative $\mathbf{4}$, that is, the central 1,4-dioxane ring is in a chair conformation and the fructopyranose ring is in the ${ }^{2} C_{5}$ conformation. Partial steric release can only be achieved at the expense of conformational distortion of the furanose ring. In contrast, the vicinal proton-proton coupling constants around the $\alpha$ fructopyranose ring in $\mathbf{1 9}$ evidenced a profound conformational change as compared with reported data for DFAs incorporating this structural subunit, ${ }^{2}$ including 5. Thus, the presence of the $o$-xylylene bridge causes the flip of the ${ }^{5} C_{2}$ conformation $\left(J_{3^{\prime}, 4^{\prime}}=3.2 \mathrm{~Hz}\right.$ for 5$)$ to the reverse ${ }^{2} C_{5}$ disposition $\left(J_{3^{\prime}, 4^{\prime}}=7.9 \mathrm{~Hz}\right.$ for 19). Simultaneously, the central 1,4-dioxane ring shifts to a skew-boat arrangement, as seen by NOE contacts, thereby bringing closer the bridged positions $\left(\mathrm{d}_{\mathrm{O}-6-\mathrm{O}-3^{\prime}}=3.2 \AA\right)$. The energetic cost of losing an anomeric effect stabilization is then overcome by the release in the steric constrain imposed by the spacer.

In summary, the above results broaden the concept of rigid-spacer-mediated spirocyclization by taking advantage not only of distance restrictions but also of subtle molecular flexibility differences. The combination of both aspects provides alternative opportunities for the stereoselective synthesis of complex bis-spiroketal frameworks. The potential of the approach is illustrated by the rational design of efficient syntheses for the nonsymmetrical furanose-pyranose difructose dianhydrides $\mathbf{4}$ and $\mathbf{5}$.

\section{Acknowledgment}

We thank the Spanish Ministerio de Educación y Ciencia (contract numbers CTQ2004-05854/BQU and CTQ2006-15515-C02-01/ BQU) and the Junta de Andalucía (P06-AGR-02115) for financial support.

\section{References and Notes}

(1) Permanent address: Department of Chemistry, Faculty of Sciences, University of Alexandria, P.O. Box 426 Ibrahimia, 21321 Alexandria, Egypt.

(2) For reviews, see: (a) Brimble, M. A.; Furkert, D. P. Curr. Org. Chem. 2003, 7, 1. (b) Brimble, M. A.; Farès, F. A. Tetrahedron 1999, 55, 7661. For selected recent references, see: (c) Georgiu, T.; Tofi, M.; Montagnon, T.;

Vassilikogiannakis, G. Org. Lett. 2006, 8, 1945. (d) Zhou, X.-T.; Carter, R. G. Angew. Chem. Int. Ed. 2006, 45, 1787. (e) Fürstner, A.; Fenster, M. D. B.; Fasching, B.; Godbout, C.; Radkowski, K. Angew. Chem. Int. Ed. 2006, 45, 5510. (f) Liu, J.; Yang, J. H.; Ko, C.; Hsung, R. P. Tetrahedron Lett. 2006, 47, 6121. (g) Meilert, K.; Brimble, M. A. Org. Biomol. Chem. 2006, 4, 2184. (h) Paterson, I.; Anderson, E. A.; Dalby, S. M.; Lim, J. H.; Maltas, P.; Moessner, C. Chem. Commun. 2006, 4186. (i) Halim, R.; Brimble, M. A.; Merten, J. Org. Lett. 2005, 7, 2659. (j) Sofikiti, N.; Montagnon, T.; Vassilikogiannakis, G.; Stratakis, M. Org. Lett. 2005, 7, 2357. (k) Paterson, I.; Anderson, E. A.; Dalby, S. M.; Loiseleur, O. Org. Lett. 2005, 7, 4121.

(3) For a review, see: Manley-Harris, M.; Richards, G. N. Adv. Carbohydr. Chem. Biochem. 1997, 52, 207.

(4) (a) Defaye, J.; García Fernández, J. M. Carbohydr. Res. 1994, 256, C1. (b) Defaye, J.; García Fernández, J. M. Zuckerindustrie 1995, 120, 700. (c) Manley-Harris, M.; Richards, G. N. Carbohydr. Res. 1996, 287, 183.

(d) Ratsimba, V.; García Fernández, J. M.; Defaye, J.; Nigay, H.; Voilley, A. J. Chromatogr., A 1999, 844, 283. (e) Christian, T. J.; Manley-Harris, M.; Field, R. J.; Parker, B. A. J. Agric. Food Chem. 2000, 48, 1823. (f) Montilla, A.; Ruiz-Matute, A. I.; Martínez-Castro, I.; del Castillo, M. D. Food Res. Int. 2006, 39, 801. (g) Böhm, A.; Klessen, B.; Henle, T. Eur. Food Res. Technol. 2006, 222, 737. 
(5) (a) Enderlin, G.; Taillefumier, C.; Didierjean, C.; Chapleur, Y. Tetrahedron: Asymmetry 2005, 16, 2459. (b) vant Hooft, P. A. V.; Oualid, F. E.; Overkleeft, H. S.; van der Marel, G. A.; van Boom, J. H.; Leeuwenburgh, M. A. Org. Biomol. Chem. 2004, 2, 1395. (c) Tatibouët, A.; Lawrence, S.; Rollin, P.; Holman, G. D. Synlett 2004, 1945. (d) Jang, K.H.; Ryu, E.-J.; Park, B.-S.; Song, K.-B.; Kang, S. A.; Kim, C. H.; Uhm, T.-B.; Park, Y.-I.; Rhee, S.-K. J. Agric. Food Chem. 2003, 51, 2632. (e) Li, X.; Takahashi, H.; Ohtake, H.; Shiro, M.; Ikegami, S. Tetrahedron 2001, 57, 8053.

(f) García Fernández, J. M.; Ortiz Mellet, C.; Defaye, J. J. Org. Chem. 1998, 63, 3572. (g) Bextermöller, R.; Redlich, H.; Schnieders, K.; Thormählen, S.; Fröhlich, R. Angew. Chem. Int. Ed. 1998, 37, 2496. (h) García Fernández, J. M.; Schnelle, R.-R.; Defaye, J. Aust. J. Chem. 1996, 49, 319. (i) García Fernández, J. M.; Schnelle, R.-R.; Defaye, J. Tetrahedron: Asymmetry 1995, 6, 307.

(6) (a) Defaye, J.; Gadelle, A.; Pedersen, C. Carbohydr. Res. 1985, 136, 53. (b) Defaye, J.; García Fernández, J. M. Carbohydr. Res. 1994, 251, 1. (c) Defaye, J.; García Fernández, J. M. Carbohydr. Res. 1994, 251, 17.

(7) Defaye, J.; García Fernández, J. M. Carbohydr. Res. 1992, 237, 223.

(8) (a) Benito, J. M.; Gómez-García, M.; Ortiz Mellet, C.; García Fernández, J. M.; Defaye, J. Org. Lett. 2001, 3, 549. (b) Benito, J. M.; Rubio, E. M.; Gómez-G arcía, M.; Ortiz Mellet, C.; García Fernández, J. M. Tetrahedron 2004, 60, 5899. (c) Balbuena, P.; Rubio, E. M.; Ortiz Mellet, C.; García Fernández, J. M. Chem. Commun. 2006, 2610.

(9) (a) Rubio, E. M.; García-Moreno, M. I.; Balbuena, P.; Lahoz, F. J.; Alvarez, E.; Ortiz Mellet, C.;

García Fernández, J. M. J. Org. Chem. 2006, 71, 2257. (b) Rubio, E. M.; Ortiz Mellet, C.; García Fernández, J. M. Org. Lett. 2003, 5, 873.

(10) (a) Müller, M.; Huchel, U.; Geyer, A.; Schmidt, R.-R. J. Org. Chem. 1999, 64, 6190. (b) Jung, K.-H.; Müller, M.; Schmidt, R.-R. Chem. Rev. 2000, 100, 4423. (c) Müller, M.; Schmidt, R.-R. Eur. J. Org. Chem. 2001, 2055.

(11) The term 'contra-thermodynamic' designates diastereomers that are energetically strongly disfavored and, consequently, cannot be accessed under reversible kinetics or thermodynamic conditions. For examples of stereoselective syntheses of contra-thermodynamic spiroacetals, see: (a) Takaoka, L. R.; Buckmelter, A. J.; LaCruz, T. E.; Rychnovsky, S. D. J. Am. Chem. Soc. 2005, 127, 528. (b) LaCruz, T. E.; Rychnovsky, S. D. Org. Lett. 2005, 7, 1873.

(12) (a) Brady, R. F. Jr. Adv. Carbohydr. Chem. Biochem. 1971, 26, 197. (b) Lichtenthaler, F. W. Carbohydr. Res. 1998, 313, 69.

(13) 4,5-Di-O-benzyl-3-O-(3-bromomethylbenzyl)-1,2-Oisopropylidene- $\beta$ - $d$-fructopyranose (13)

To a solution of 1,3-bis(bromomethyl)benzene (1.99 g, 7.56 mmol, 2 equiv) in anhyd DMF $(50 \mathrm{~mL}), \mathrm{NaH}(60 \%$ in mineral oil, $378 \mathrm{mg}, 9.45 \mathrm{mmol}$ ) was added and the suspension was stirred at r.t. for $15 \mathrm{~min}$. Compound $\mathbf{1 0}^{12}$ $(1.0 \mathrm{~g}, 3.78 \mathrm{mmol})$ was then added and the reaction mixture was further stirred for $24 \mathrm{~h}$. Afterwards, $\mathrm{Et}_{2} \mathrm{O}(15 \mathrm{~mL})$ and $\mathrm{H}_{2} \mathrm{O}(15 \mathrm{~mL})$ were added, the organic layer was separated, washed with $\mathrm{H}_{2} \mathrm{O}(5 \times 10 \mathrm{~mL})$, dried $\left(\mathrm{MgSO}_{4}\right)$, filtered, and concentrated. The resulting residue was purified by column chromatography (EtOAc-PE, 1:10) to yield $\mathbf{1 1}(955 \mathrm{mg}$, $57 \%$ ). Compound 11 (400 mg, $0.9 \mathrm{mmol}$ ) was dissolved in $60 \%$ aq $\mathrm{AcOH}(2.4 \mathrm{~mL})$ and stirred at $45^{\circ} \mathrm{C}$ for $2 \mathrm{~h}$. The reaction mixture was then diluted with $\mathrm{H}_{2} \mathrm{O}(5 \mathrm{~mL})$ and extracted with EtOAc $(4 \times 4 \mathrm{~mL})$. The combined organic phase was washed with sat. aq $\mathrm{NaHCO}_{3}(6 \mathrm{~mL})$, dried
$\left(\mathrm{MgSO}_{4}\right)$, filtered, and concentrated. The resulting residue was purified by column chromatography (EtOAc-PE, 2:1) to give $\mathbf{1 2}$ (254 mg, 70\%). Conventional benzylation of $\mathbf{1 2}$ (323 mg, $0.80 \mathrm{mmol}$ ) with $\mathrm{NaH} / \mathrm{BnBr}$ afforded 13 (303 mg, $65 \%)$.

(14) General Procedure for the Preparation of $\left(O-6 \rightarrow O-3^{\prime}\right)-$ Xylylene-Tethered Fructofuranose-Fructopyranose Derivatives (15 and 18)

To a solution of 2,3-di- $O$-benzyl-1,2- $O$-isopropylidene- $\beta$-Dfructofuranose $14^{9 \mathrm{a}}(188 \mathrm{mg}, 0.47 \mathrm{mmol})$ in dry DMF (3 $\mathrm{mL}), \mathrm{NaH}$ (60\% in mineral oil, $46 \mathrm{mg}, 0.98 \mathrm{mmol})$ was added and the reaction mixture was stirred at r.t. for $1 \mathrm{~h}$. A solution of 13 or $17^{13}(225 \mathrm{mg}, 0.39 \mathrm{mmol})$ in anhyd DMF $(4 \mathrm{~mL})$ was then added, the reaction mixture was further stirred at r. t. for $3 \mathrm{~h}$, quenched by addition of $\mathrm{H}_{2} \mathrm{O}(2 \mathrm{~mL})$, concentrated and the resulting residue was purified by column chromatography using EtOAc-toluene (1:6) as eluent to give $\mathbf{1 5}(190 \mathrm{mg}, 54 \%)$ or $\mathbf{1 8}(220 \mathrm{mg}, 62 \%)$.

(15) General Procedure for Xylylene-Mediated Synthesis of Type II DFA Derivatives $(16,19$, and 20)

To a solution of the corresponding $m$ - or $o$-xylylene-tethered precursor 15 or $18(280 \mathrm{mg}, 0.31 \mathrm{mmol})$ in $\mathrm{CH}_{2} \mathrm{Cl}_{2}(20 \mathrm{~mL})$ at $-78{ }^{\circ} \mathrm{C}$ under Ar, TfOH $(41 \mu \mathrm{L})$ was added. The reaction mixture was allowed to reach r.t. and stirred for $1 \mathrm{~h}$, then quenched by addition of $\mathrm{Et}_{3} \mathrm{~N}(0.1 \mathrm{~mL})$ and concentrated. Column chromatography of the resulting residue $(1: 3 \rightarrow 1: 1$ EtOAc-PE for 15; 1:5 $\rightarrow$ 1:2 EtOAc-PE for 18) afforded $\mathbf{1 6}$ (142 $\mathrm{mg}, 59 \%)$ or $19(48.7 \mathrm{mg}, 20.8 \%)$ and $20(72.8 \mathrm{mg}$, $31.2 \%$ ), respectively, as the only intramolecular reaction products.

(16) Selected data for 16: $[\alpha]_{\mathrm{D}}^{22}+10.1\left(c 0.9, \mathrm{CHCl}_{3}\right) .{ }^{1} \mathrm{H}$ NMR $\left(500 \mathrm{MHz}, \mathrm{CDCl}_{3}\right): \delta=4.16\left(\mathrm{~d}, 1 \mathrm{H}, J_{1 \mathrm{a}^{\prime}, 1 \mathrm{~b}^{\prime}}=11.6 \mathrm{~Hz}, \mathrm{H}-\right.$ 1'a), 4.14 (m, $1 \mathrm{H}, \mathrm{H}-5), 4.00$ (d, $\left.1 \mathrm{H}, J_{3,4}=2.5 \mathrm{~Hz}, \mathrm{H}-3\right)$, 3.99 (m, $1 \mathrm{H}, \mathrm{H}-6 \mathrm{a}), 3.96$ (d, $\left.1 \mathrm{H}, J_{1 \mathrm{a}, 1 \mathrm{~b}}=11.8 \mathrm{~Hz}, \mathrm{H}-1 \mathrm{a}\right)$, $3.94\left(\mathrm{dd}, 1 \mathrm{H}, J_{3^{\prime}, 4^{\prime}}=9.5 \mathrm{~Hz}, J_{4^{\prime} 5^{\prime}}=3.2 \mathrm{~Hz}, \mathrm{H}-4^{\prime}\right), 3.83(\mathrm{~d}, 2$ $\left.\mathrm{H}, J_{6 \mathrm{a}^{\prime}, 6 \mathrm{~b}^{\prime}}=12.0 \mathrm{~Hz}, \mathrm{H}-6^{\prime} \mathrm{a}, \mathrm{H}-1 \mathrm{~b}\right), 3.74$ (m, $\left.1 \mathrm{H}, \mathrm{H}-6 \mathrm{~b}\right), 3.72$ (m, $\left.1 \mathrm{H}, \mathrm{H}-5^{\prime}\right), 3.61$ (d, $\left.1 \mathrm{H}, \mathrm{H}-3^{\prime}\right), 3.60$ (d, $\left.1 \mathrm{H}, \mathrm{H}-6^{\prime} \mathrm{b}\right), 3.54$ $\left(\mathrm{dd}, 1 \mathrm{H}, J_{4,5}=7.5 \mathrm{~Hz}, \mathrm{H}-4\right), 3.39\left(\mathrm{~d}, 1 \mathrm{H}, \mathrm{H}-1{ }^{\prime} \mathrm{b}\right) .{ }^{13} \mathrm{C} \mathrm{NMR}$ $\left(125.7 \mathrm{MHz}, \mathrm{CDCl}_{3}\right): \delta=102.3(\mathrm{C}-2), 95.9\left(\mathrm{C}-2^{\prime}\right), 89.0(\mathrm{C}-$ 3), 85.1 (C-4), 80.1 (C-5), 78.9 (C-3'), 78.6 (C-4'), 73.5 (C5'), $75.8\left(\mathrm{CH}_{2} \mathrm{Ph}\right), 74.8(\mathrm{C}-6), 74.3,72.5,72.3,71.2$ $\left(\mathrm{CH}_{2} \mathrm{Ph}\right), 62.5\left(\mathrm{C}-1^{\prime}\right), 62.0(\mathrm{C}-1), 60.3\left(\mathrm{C}-6^{\prime}\right)$. MS-FAB: $m / z(\%)=809(60)[\mathrm{M}+\mathrm{Na}]^{+}$. Anal. Calcd for $\mathrm{C}_{48} \mathrm{H}_{50} \mathrm{O}_{10}: \mathrm{C}$, 73.26; H, 6.40. Found: C, 73.07; H, 6.07.

(17) General Procedure for the Synthesis of Fully Unprotected DFAs (4 and 5)

Catalytic hydrogenation of 16 and 19 or $20(0.038 \mathrm{mmol})$ with $10 \% \mathrm{Pd} / \mathrm{C}$ in EtOAc-MeOH $(1: 1)$ containing $10 \%$ $\mathrm{HCOOH}(1 \mathrm{~mL})$ at $1 \mathrm{~atm}$ overnight, afforded the fully unprotected bis-spiro fructodisaccharide $\mathbf{4}$ or $\mathbf{5}$ in quantitative yield having physicochemical properties identical to those reported. ${ }^{2,4 d}$

(18) Rubio, E. M.; García-Moreno, M. I.; Balbuena, P.; Ortiz Mellet, C.; García Fernández, J. M. Org. Lett. 2005, 7, 729.

(19) Selected data for 19: $[\alpha]_{\mathrm{D}}^{22}+4.9\left(c 0.8, \mathrm{CHCl}_{3}\right) .{ }^{1} \mathrm{H}$ NMR $\left(500 \mathrm{MHz}, \mathrm{CDCl}_{3}\right): \delta=4.06\left(\mathrm{~d}, 1 \mathrm{H}, J_{6 \mathrm{a}, 6 \mathrm{~b}}=12.6 \mathrm{~Hz}, \mathrm{H}-6 \mathrm{a}\right)$, 4.01 (br d, $\left.1 \mathrm{H}, J_{4,5}=8.7 \mathrm{~Hz}, \mathrm{H}-5\right), 3.98\left(\mathrm{dd}, 1 \mathrm{H}, J_{3^{\prime} 4^{\prime}}=9.7\right.$ $\left.\mathrm{Hz}, J_{4^{\prime}, 5^{\prime}}=3.1 \mathrm{~Hz}, \mathrm{H}-4^{\prime}\right), 3.88$ (d, $1 \mathrm{H}, J_{3,4}=3.7 \mathrm{~Hz}, \mathrm{H}-3$ ), $3.86\left(\mathrm{~d}, 1 \mathrm{H}, J_{1 \mathrm{a}, 1 \mathrm{~b}}=13.7 \mathrm{~Hz}, \mathrm{H}-1 \mathrm{a}\right), 3.84(\mathrm{~m}, 1 \mathrm{H}, \mathrm{H}-6 \mathrm{~b})$, $3.72\left(\mathrm{dd}, \mathrm{H}, J_{6 \mathrm{a}^{\prime}, 6 \mathrm{~b}^{\prime}}=11.5 \mathrm{~Hz}, J_{5^{\prime}, 6 \mathrm{a}^{\prime}}=3.0 \mathrm{~Hz}, \mathrm{H}-6^{\prime} \mathrm{a}\right), 3.71(\mathrm{~m}$, $\left.1 \mathrm{H}, \mathrm{H}-5^{\prime}\right), 3.70$ (d, $\left.1 \mathrm{H}, \mathrm{H}-1 \mathrm{~b}\right), 3.65$ (d, $\left.1 \mathrm{H}, \mathrm{H}-6^{\prime} \mathrm{b}\right), 3.61$ (dd, $1 \mathrm{H}, \mathrm{H}-4), 3.55$ (d, $\left.1 \mathrm{H}, \mathrm{H}-3^{\prime}\right), 3.39$ (d, $1 \mathrm{H}, J_{1 \mathrm{a}^{\prime}, 1 \mathrm{~b}^{\prime}}=12.0 \mathrm{~Hz}$, $\left.\mathrm{H}-1^{\prime} \mathrm{a}\right), 3.05$ (d, $\left.1 \mathrm{H}, \mathrm{H}-1^{\prime} \mathrm{b}\right) .{ }^{13} \mathrm{C} \mathrm{NMR}\left(125.7 \mathrm{MHz}, \mathrm{CDCl}_{3}\right.$ ): $\delta=102.0(\mathrm{C}-2), 95.2\left(\mathrm{C}-2^{\prime}\right), 88.8(\mathrm{C}-3), 86.2(\mathrm{C}-4), 79.6(\mathrm{C}-$ 5), 78.9 (C-4'), 74.5 (C-3'), 73.4 (C-5'), 72.9, 72.5, 72.4, 72.0, $71.4\left(\mathrm{CH}_{2} \mathrm{Ph}\right), 71.2(\mathrm{C}-6), 68.5\left(\mathrm{CH}_{2} \mathrm{Ph}\right), 62.6\left(\mathrm{C}-1^{\prime}\right)$, 
$62.4(\mathrm{C}-1), 60.6\left(\mathrm{C}-6^{\prime}\right)$. ESI-MS: $m / z=809[\mathrm{M}+\mathrm{Na}]^{+}$. Anal. Calcd for $\mathrm{C}_{48} \mathrm{H}_{50} \mathrm{O}_{10}$ : C, 73.26; H, 6.40. Found: C, 73.13; H, 6.48.

(20) Selected data for 20: $[\alpha]_{\mathrm{D}}{ }^{22}+18.1\left(c 1.0, \mathrm{CHCl}_{3}\right) .{ }^{1} \mathrm{H} \mathrm{NMR}$ $\left(500 \mathrm{MHz}, \mathrm{CDCl}_{3}\right): \delta=4.59\left(\mathrm{~d}, 1 \mathrm{H}, J_{1 \mathrm{a}, 1 \mathrm{~b}}=12.5 \mathrm{~Hz}, \mathrm{H}-1 \mathrm{a}\right)$, $4.24\left(\mathrm{dt}, 1 \mathrm{H}, J_{5,6 \mathrm{~b}}=10.5 \mathrm{~Hz}, J_{5,6 \mathrm{a}}=J_{4,5}=4.5 \mathrm{~Hz}, \mathrm{H}-5\right), 4.19$ $\left(\mathrm{d}, 1 \mathrm{H}, J_{1 \mathrm{a}^{\prime}, 1 \mathrm{~b}^{\prime}}=11.4 \mathrm{~Hz}, \mathrm{H}-1^{\prime} \mathrm{a}\right), 4.15\left(\mathrm{~d}, 1 \mathrm{H}, J_{3^{\prime}, 4^{\prime}}=7.9 \mathrm{~Hz}\right.$, H-3'), 4.13 (dd, $\left.1 \mathrm{H}, J_{3,4}=6.3 \mathrm{~Hz}, \mathrm{H}-4\right), 4.05$ (dd, $1 \mathrm{H}$, $\left.J_{6 \mathrm{a}^{\prime}, 6 \mathrm{~b}^{\prime}}=12.2 \mathrm{~Hz}, J_{5^{\prime}, 6 \mathrm{a}^{\prime}}=5.8 \mathrm{~Hz}, \mathrm{H}-6^{\prime} \mathrm{a}\right), 3.87$ (d, $\left.1 \mathrm{H}, \mathrm{H}-3\right)$, $3.74\left(\mathrm{dt}, 1 \mathrm{H}, J_{4^{\prime}, 5^{\prime}}=J_{5^{\prime}, 6 \mathrm{~b}^{\prime}}=3.0 \mathrm{~Hz}, \mathrm{H}-5^{\prime}\right), 3.70(\mathrm{~d}, 1 \mathrm{H}, \mathrm{H}-$ 1b), 3.65 (dd, $\left.1 \mathrm{H}, J_{6 \mathrm{a}, 6 \mathrm{~b}}=10.5 \mathrm{~Hz}, \mathrm{H}-6 \mathrm{a}\right), 3.60(\mathrm{t}, 1 \mathrm{H}, \mathrm{H}-$ 6b), 3.52 (d, $\left.1 \mathrm{H}, \mathrm{H}-1^{\prime} \mathrm{b}\right), 3.45$ (dd, $\left.1 \mathrm{H}, \mathrm{H}-6^{\prime} \mathrm{b}\right), 3.41$ (dd, 1 $\left.\mathrm{H}, \mathrm{H}-4^{\prime}\right) .{ }^{13} \mathrm{C}$ NMR $\left(125.7 \mathrm{MHz}, \mathrm{CDCl}_{3}\right): \delta=101.4(\mathrm{C}-2)$, 97.7 (C-2'), 85.1 (C-4), 84.7 (C-3), 79.0 (C-5), 78.0 (C-3'), $76.3\left(\mathrm{C}-4^{\prime}\right), 72.9,72.7,72.0\left(\mathrm{CH}_{2} \mathrm{Ph}\right), 71.9(\mathrm{C}-6), 71.6(\mathrm{C}-$ $\left.5^{\prime}\right), 71.2,70.9,70.2\left(\mathrm{CH}_{2} \mathrm{Ph}\right), 63.8\left(\mathrm{C}-1^{\prime}\right), 61.0\left(\mathrm{C}^{\prime} 6^{\prime}\right), 59.8$ (C-1). ESI-MS: $m / z=809[\mathrm{M}+\mathrm{Na}]^{+}$. Anal. Calcd for $\mathrm{C}_{48} \mathrm{H}_{50} \mathrm{O}_{10}$ : C, 73.26; H, 6.40. Found: C, 73.13; H, 6.06. 